\title{
Characterising urban concentration and land-use diversity in simulations of future land use
}

\author{
Jan Ritsema van Eck • Eric Koomen
}

Received: 24 March 2006 / Revised: 30 June 2006 / Published online: 25 July 2007

(C) Springer-Verlag 2007

\begin{abstract}
This paper presents two sets of functional indicators that were implemented and tested for the assessment of spatial aspects of future land-use configurations as simulated by a land-use model. This is potentially useful for the ex-ante evaluation of spatial planning policies. The indicators were applied in a Dutch case study and relate to two important themes in Dutch spatial planning: compact urbanisation and mixing of land uses. After a short introduction of these themes, the sets of indicators are presented which are used for their evaluation. These indicators are applied to simulations based on two scenarios for land-use development in the Netherlands up to 2030. After a discussion of the results we conclude that the combined application of land-use models and indicators produces new and potentially useful information for policy makers, although both the model and the associated indicators are still in a state of development.
\end{abstract}

JEL Classification $\mathrm{C} 15 \cdot \mathrm{C} 53 \cdot \mathrm{R} 14 \cdot \mathrm{R} 52$

\section{Introduction}

Influencing future land-use patterns may be considered the direct objective of spatial planning. One instrument to achieve this is land-use zoning. But passively regulating citizens' land use is not the only way in which national and local governments try to achieve their spatial planning aims. They also play a more active role in shaping the

\footnotetext{
J. Ritsema van Eck ( $ه)$

Netherlands Institute for Spatial Research, The Hague, The Netherlands e-mail: ritsemavaneck@rpb.nl

E. Koomen

Faculty of Economics and Business Administration, Vrije Universiteit Amsterdam, Amsterdam, The Netherlands
} 
future landscape, for instance by careful allocation of their own spatial investments, as well as funds for different types of infrastructure, and by public private partnerships and other measures to involve private parties in their planning efforts. In the end, future land-use patterns are the result of actions by a multitude of actors. In this complex playing field, it is important to have an instrument for ex-ante evaluation of the spatial effects of planning measures. A land-use model is such an instrument, provided that it can offer valid and reliable indicators for the achievement of relevant spatial objectives. In this paper we discuss two such objectives, concentration of urbanisation and mixing of land uses, and potentially useful indicators for these objectives, illustrated with results from a Dutch case study.

\subsection{Land-use modelling for policy support}

Land-use models are a common tool to inform spatial planners of the possible developments they face. Numerous applications are discussed in for example: Veldkamp et al. (2001), Agarwal et al. (2002) and Koomen et al. (2007). Future land use is an especially important theme in studies related to the preparation and evaluation of largescale spatial plans and strategies. These studies typically look several decades ahead and describe the outlook of the future by means of a set of scenarios with different socio-economic conditions. Land-use models are used here to indicate possible future land-use patterns according to the specified scenario conditions, as is demonstrated in numerous applications (de Nijs et al. 2004; Solecki and Oliveri 2004; Frenkel 2004). Since scenarios can also contain reference to actual or envisaged spatial policies, the simulations can confront policymakers with the possible outcomes of their decisions.

While the current generation of land-use change models still faces a number of challenges regarding, for example, the integration of social, economic and spatial sciences at different scales, the quantification of neighbourhood effects and the inclusion of temporal dynamics, they are generally considered to be useful for policy-making (Veldkamp and Lambin 2001; Verburg et al. 2004; Verburg and Veldkamp 2005). The use of the scenario method in this context offers a structured approach to deal with the many uncertainties related to future developments. Scenario simulation results are, however, heavily reliant on expert judgement, so their validity is questionable. This is inherent to the scenario approach, as is also discussed by Klosterman (1999) in his description of the What if? scenario-based planning support system. The limited validity is not a serious problem as long as the simulation outcomes are treated for what they are worth: images depicting possible future developments following a large number of scenario-related assumptions.

In order to help policy-makers and researchers interpret, compare and evaluate different scenario simulations quantitative measures are needed that objectively describe the resulting maps. McGarigal (2002) distinguishes two types of indicators that can help summarise maps of future land use. General composition metrics quantify the variety and abundance of land-use types without considering their spatial character, whereas spatial configuration metrics do refer to the spatial distribution of the various land-use types and focus on their individual patches, i.e. areas of a specific land-use type. In combination both types of indicators can be effectively applied 
to evaluate simulation results in terms of spatial policy issues. It is especially this dedicated assessment of land-use maps that is essential to decision-makers. Functional indicators should: relate to specific (policy) themes, be intuitively understandable for policymakers, capture the essence of simulation results and discriminate between different simulation outcomes.

Applications of spatial configuration indices are numerous in studies dealing with land-use/land-cover change, especially when focussed on the aspect of landscape ecology (see e.g. Gustafson 1998; Jaeger 2000; Nagendra et al. 2004). Other applications of spatial-pattern indicators in land-use simulation studies are related to, for example, the assessment of changes in forest resources (Verburg and Veldkamp 2004) and the analysis of urbanisation patterns in the United States following cellular automata simulations (Jenerete and Wu 2001; Yang and Lo 2003).

In this study, we select and implement a number of quantitative measures for assessing the concentration of urbanisation and land-use diversity for use in a grid based land-use modelling system. The proposed indicators deal with both map composition and spatial configuration and range in detail from single-value indices at the national level to indicators with spatially varying output at the level of individual urban areas and single grid cells. The proposed indicators are tested in simulations of future land use that are based on two long term scenarios for the spatial development of the Netherlands until 2030. A rather specific element in our simulations is the use of heterogeneous grid cells that describe the relative proportion of a number of land-use types at that specific location. This non-typical data representation poses special challenges in the construction of the indicators, but also provides the possibility to assess land-use diversity at a relatively detailed level.

\subsection{Concentration of urbanisation}

Containing the large-scale, land-consuming urbanisation processes, often referred to as urban sprawl, is a key issue in spatial planning. This theme has been the topic of heated debate in the United States especially (e.g. Brueckner 2000; Glaeser and Kahn 2004), leading to the proposition of planning concepts as New Urbanism and Smart Growth (Hall 1998). The objective of concentrated urbanisation has also been a constant in Dutch spatial planning. Maintaining the characteristic cluster of towns and open spaces in the west of the country, known as the Randstad, was a crucial issue ever since the first Dutch report that related to physical planning (RNP 1958). The various planning reports that were subsequently drafted by the Ministry responsible for public housing and spatial planning (V\&B 1960; V\&RO 1966, 1977; VROM 1989) aimed to concentrate urbanisation either in a limited number of New Towns or in large-scale compact developments adjacent to existing cities. See Dieleman et al. (1999) for a more complete discussion on the Dutch compact city policies. The latest planning report (VROM/LNV/V\&W/EZ 2004) maintains these principles. It is clear therefore that compactness of urbanisation in some form or another has been a constant policy aim in the Netherlands for the past half century. 


\subsection{Land-use diversity}

A more recent spatial planning objective in the Netherlands is the mixing of different land-use types, in both urban and rural areas. For most of the twentieth century different land uses became more and more separated in space. This trend was supported by various spatial policies. In urbanised areas, separation of functions became possible with the transport revolution and became a guiding principle for planning with the Charter of Athens from 1933; this trend reached its zenith in the large-scale, uniform residential areas and ditto work areas built in the 1960s and 1970s. As a subsequent counter-reaction, mixing of urban land uses and activities came to be seen as an important aspect of spatial quality in urban areas. It was one of the strategies proposed by the New Urbanists and the Smart Growth movement to create the conditions for sustainable economic growth in urban areas (for a historic overview see Vreeker et al. 2004). In the late 1980s and early 1990s the concepts of mixed and multifunctional land use became popular in Dutch planning practice. For instance the latest planning report (VROM/LNV/V\&W/EZ 2004) mentions them several times as ways to enhance both spatial quality and efficiency of land use in urban areas. In rural areas too, land use has become more monofunctional in the past century, under the influence of EC agricultural policy which aimed at efficient, large-scale food production. In the Netherlands, land consolidation was implemented for this goal. Especially in smallscale agricultural landscapes (in the eastern and southern parts of the country), this led to a loss of characteristic landscape elements such as historic farmhouses, small patches of wood, hedgerows et cetera. Mixing of land use is now seen as an impulse for the quality of these areas: a combination of agriculture, small scale residential development and new nature and recreation-areas brings back some of the original small scale of these landscapes. An example of this new trend is the development of 'new country estates' as is discussed by amongst others NAI (2004) and van Dam et al. (2005).

In the following section, we shortly introduce the model and scenarios that were used. Section 3 discusses measures for the concentration of urbanisation and shows the results of their application to the scenario simulations. Section 4 is devoted to measures of mixing of land uses and their application to the scenarios. In Sect. 5 we will discuss the results in terms of what they tell us about the model that we used and finally, in terms of their usefulness for policy makers.

\section{Simulating future land use}

For our research we use the Land Use Scanner, an integrated land-use model that was applied in various policy related research projects in the Netherlands. Applications include, for example, the evaluation of alternatives for a new national airport (Scholten et al. 1999) and the preparation of the Fifth National Physical Planning Report (Schotten et al. 2001). A full description of the model is given by Hilferink and Rietveld (1999). In this section, we will shortly introduce the model and the scenarios that were defined to describe possible future developments. 


\subsection{Model characteristics}

The Land Use Scanner is a GIS-based land-use model that simulates future land use and offers an integrated view on all types of land use. It deals with urban, natural and agricultural functions, in our case distinguishing 14 different land-use categories: water, nature/woodland, agricultural nature management, grassland, arable land, greenhouses, intensive livestock keeping, recreational areas, rural residential land, urban residential land, commercial land, railroads, roads and airports. Land-use data for the base year are based on data from Statistics Netherlands (1996). The model is grid-based and this application uses almost 200,000 cells of 500 by $500 \mathrm{~m}$ to cover the Netherlands. Each cell describes the relative proportion of all land-use types with a resolution of 1 ha (that is $1 / 25$ of the grid cell), i.e. a cell can contain more than one type of land use. It thus presents a highly disaggregated description of the whole country. External regional predictions of land-use change from, for example, sector-specific models of specialized institutes are used as input for the model. The predicted amount of change for each land-use type is considered as an additional claim to its current surface area. The total of the additional claim and the present area is, for each land-use category, allocated to individual grid-cells based on the suitability of the cell. Suitability maps are generated for all different land-use types based on location characteristics of the grid cells in terms of physical properties, operative policies and expected relations to nearby land-use functions. Unlike many other land-use models the objective of the Land Use Scanner is not to forecast the dimension of land-use change but rather to integrate and allocate future land-use claims from different sector-specific models. The model employs a logit-type approach, derived from discrete choice theory, to simulate the probability that a certain location is chosen for a specific land use. The crucial variable for the allocation model is the suitability of each grid cell for each type of land use. This suitability can be interpreted to represent the net benefits (benefits minus costs) of a particular land-use type in a particular cell. The higher the benefits (suitability) for that land-use type, the higher the probability that the cell will be used for that type. The economic rationale that motivates this choice behaviour resembles the actual functioning of the land market. The model is furthermore constrained by two conditions: the overall demand for the land-use functions which is given in the initial claims and the total amount of land that is available.

\subsection{Defining scenarios}

To provide a coherent framework for studying possible future developments we have selected two scenarios for future spatial developments from the National Nature Outlook study (MNP 2002). These are in turn based on previous IPCC-scenarios and follow each two opposing trends: 'Individualistic World' combines globalisation with individualism, whereas 'Cooperating Region' connects regionalism with cooperation. In the first scenario the free market is an important ingredient. Government intervention in both the functioning of the agricultural market and spatial policy is limited. In the latter scenario equity and national sovereignty prevail. The European agricultural market is expected to partly remain protected and restrictive spatial policies will 
apply on many rural areas. In a way these scenarios reflect the changeover from the socio-economic conditions in the 1990s (Cooperating Region) to the neo-liberal outlook on life (Individualistic World) as is advocated in the new Dutch Spatial Policy report (VROM/LNV/V\&W/EZ 2004). The scenarios thus offer a way of comparing the outcomes of two opposing political strategies on spatial planning. The story-lines of the scenarios were subsequently fed into sector-specific regional models to quantify the expected demand for various types of land use, e.g. residential, commercial and natural. The demand for agricultural land was estimated by using the land-market model developed by the Agricultural Economics Research Institute, see Koole et al. (2001). The demand from the other land-use functions was derived from various sectorspecific models, policy documents and expert judgement. See de Nijs et al. (2002) for a more detailed description of the original land-use claims and Koomen et al. (2005a) for a fuller account of the Land Use Scanner implementation.

\section{Concentration of urbanisation}

Three types of measurements of spatial concentration are distinguished by Johnston et al. (2003): (1) concentration within an area, (2) concentrations formed by a set of contiguous areas and (3) concentrations formed by proximity between a set of areas. The first type refers to density gradients within urban areas that are popular in studies on urban sprawl (e.g. Song and Knaap 2004; Allen 2001). The second type of measurements typically looks at the size and shape of individual urban constellations (e.g. Geurs and van Wee 2006; Longley and Mesev 2000). The third type of measurements analyses the spatial spread (or dispersion) of groups of urban areas. An elaborate example of this type of analysis is provided by the spatial interaction approach of Thinh et al. (2002). We will focus especially on metrics describing concentrations formed by a set of contiguous urban areas as these are most closely related to the spatial policies aimed at preserving the alternation of relatively large urban areas surrounded by sizeable non-urban (open) spaces that we want to evaluate. This focus on individual urban constellations is similar to the approach ecologists take when studying landscape patterns. Crucial in their description of changes in the landscape is the distinction of individual 'patches' that consist of a single landscape type. From their extensive work (e.g. Gustafson 1998; O’Neill et al. 1999; Turner et al. 2001), we select a limited number of indicators relating to patch-size distribution and shape complexity. This limited sample exemplifies the possible use of such indicators.

We will, however, start with discussing the different urbanisation patterns at hand by introducing a number of general composition indices and subsequently present the increase of the urbanisation degree over time per grid cell. By using this combination of composition and configuration indicators at various scales we can quantify the extent to which the urban growth differs between the scenarios and furthermore typify which simulated urban patterns are closest to the spatial planning objective of concentrated, compact urbanisation. 
Table 1 Urbanisation indicators for current and simulated land use

\begin{tabular}{|c|c|c|c|}
\hline & $\begin{array}{l}\text { Current } \\
\text { land use }\end{array}$ & $\begin{array}{l}\text { Individualistic } \\
\text { world }\end{array}$ & $\begin{array}{l}\text { Cooperating } \\
\text { region }\end{array}$ \\
\hline Total urbanised area ${ }^{\mathrm{a}}$ (ha) & 491,710 & 693,253 & 610,420 \\
\hline Urban population density (inhabitants/ha) & 31.5 & 24.7 & 30.0 \\
\hline Urbanisation degree $^{\mathrm{b}}(\%)$ & 12 & 17 & 15 \\
\hline Number of urban areas ${ }^{c}$ & 1,381 & 1,414 & 1,209 \\
\hline Average urban area size (ha) & 227 & 330 & 338 \\
\hline S.D. of urban area size ${ }^{\mathrm{d}}$ & 817 & 2,203 & 1,328 \\
\hline Skewness of urban area size & 13.6 & 20.4 & 11.2 \\
\hline Average circularity ratio & 0.27 & 0.21 & 0.24 \\
\hline
\end{tabular}

${ }^{a}$ Total of residential and commercial land use, greenhouses, intensive livestock keeping and infrastructure

${ }^{b}$ Total urbanised area as percentage of the Dutch land surface $(4,152,911$ ha)

${ }^{c}$ An urban area consists of a group of adjacent urban cells (following the eight-neighbour rule); each cell having an urbanised area of more then 15 hectare

${ }^{d}$ The urban-area size distribution has a strong positive skew (see next row) and its standard deviation is thus not normally distributed

${ }^{\mathrm{e}}$ In averaging the circularity ratio each urban area is weighted for its size

\subsection{General composition and grid cell based urbanisation degree}

The simplest indicators that describe urbanisation are the total urbanised area and the urbanisation degree. Urbanised area is defined here as the total area of all land-use types (from the 14 types mentioned in Sect. 2) that either predominantly consist of buildings or that are closely related to urban functions: residential and commercial land use, greenhouses, intensive livestock keeping and infrastructure. The urbanisation degree is calculated as the percentage of the total land surface that is considered urbanised. Table 1 shows the indicator values for both observed current and simulated future land use in our scenario study. Urban growth is strongest in the Individualistic World scenario as was to be expected from its characteristics. According to this scenario the total urbanised area grows with around 200,000 hectares to $17 \%$ of the total Dutch land surface. But also under less rosy economic conditions and with more government intervention in the Cooperating Region scenario the urbanised area increases considerably with 120,000 hectares to $15 \%$ of the land surface. It is interesting to compare the urbanised area with population for both scenarios, because the urban population density gives some insight into intensity of urban land use. At present, this urban population density (defined as total population divided by the total urbanised area) is 31.5 inhabitants/ha; in Cooperating Region this level of density is almost maintained and declines only slightly to 30.0 inhabitants/ha. In Individualistic World, urban land is used much more extensively and the overall urban population density falls to 24.7 inhabitants/ha.

The simulated urbanisation patterns in the two scenarios also show great differences, as can be demonstrated by the anticipated increase in urbanisation degree in the central Netherlands in Fig. 1. This map shows a per grid cell increase in total urban area in the 1996-2030 period. The Individualistic World scenario is characterised by 

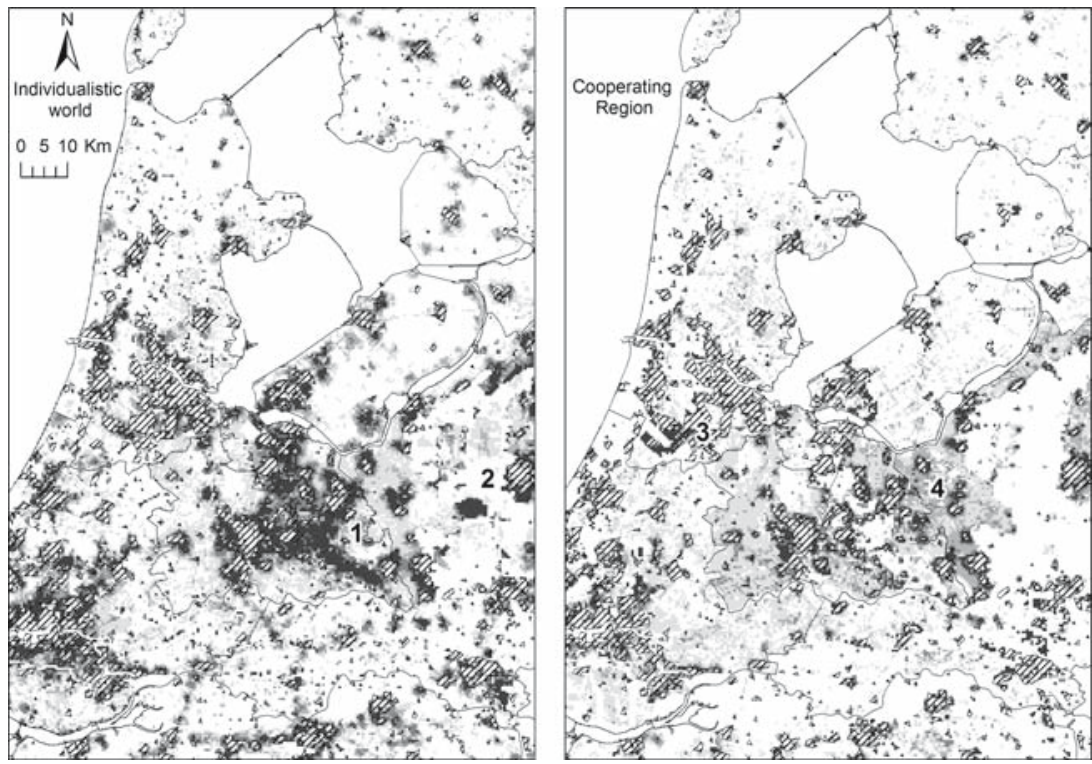

Fig. 1 Simulated increase in urban area in the two scenarios compared to current urban areas (hatched); darker colours indicate a stronger increase in the urbanisation degree per cell, the numbers are referred to in the text

extensive urbanisation of landscapes that are considered attractive for residential development (most notably forested areas). This urbanisation either covers large contiguous surfaces (indicated with number 1 in the figure) or spontaneously creates new towns (number 2). The Cooperating Region scenario shows new large-scale urban areas (3) following local urbanisation plans as well as concentric extensions of existing urban areas (4). The maps of the grid cell based urbanisation degree are very informative on the anticipated urban development, but do not capture this in a quantitative way. To actually measure the degree of urbanisation and objectively assess its correspondence to current spatial policies we will therefore apply a number of spatial configuration metrics that relate to the urban patch-size distribution.

\subsection{Patch-size distribution}

The differences between the scenarios can be captured by an adequate description of the spatial configuration of the individual urban areas. We distinguish urban areas by tracing groups of adjacent urban cells using the eight-neighbour rule. Individual urban cells are considered to be part of a greater urban form when they are bordering other urban cells in any of their eight adjacent cells (even diagonally). This method discerns extensive connected urban agglomerations that are typically much larger than individual cities. The configuration of the urban areas is most clearly described by their number and average surface area, see Table 1. The Cooperating Region scenario shows the smallest number and largest mean size of the urban areas. The number of 
urban areas is in fact smaller than in the current situation. This clearly indicates that urbanization is strongly concentrated; leading to the coalescing of currently separated individual areas. The Individualistic World scenario has the largest number of urban areas, thus indicating a more scattered urbanization pattern. The average urban area is in this case also larger than in the current situation. This is related to the strongly increased total urban area that has caused the growing of many already existing towns and not so much to a further concentration of urbanization. It should be noted that the urban-area size distribution for the current, observed situation as well as for the simulated scenario outcomes is characterized by a large number of the smallest possible areas (25 ha) areas and a decreasing number of larger areas. The distribution thus has a strong positive skew as is also reflected in the high standard deviation value. The urban area distribution is most extreme for the Individualistic World scenario that consists of a large number of new small urban areas and a few very large agglomerations, as is also indicated by the high values for the standard deviation and skewness of the urban area size.

\subsection{Shape complexity}

A more elaborate way of looking at the spatial configuration of the urban areas is to actually account for their shape complexity. Since we are interested in the concentration of urbanisation, indicators describing the compactness of forms are considered appropriate. A common measure of compactness, for example provided in the popular FRAGSTATS (McGarigal and Marks 1995) software, is the perimeter/area ratio. This indicator will describe compact shapes with low values, but has the serious disadvantage of being sensitive to the size of the shapes. A similar shape will receive lower values for this ratio with increasing size. The more elaborate shape index of Boyce and Clark (1964) has the same limitation. The popular description of fractal dimension are not suited for elongated and asymmetric shapes (Medda 2000) and therefore also discarded in this analysis. Instead we selected a size-independent measure that can be applied on any type of shape: the circularity ratio (see e.g. Selkirk 1982). This metric indicates how much a shape deviates from its smallest possible form (a circle). The more elaborate shape membership function (Medda 2000) is also shape and size independent and has the additional advantage of quantitatively describing a number of shapes, but it is much more complex to calculate. As it is our objective to only characterize compactness and not so much to differentiate between shapes as such, we prefer to apply the more straightforward circularity ratio.

The circularity ratio is calculated through

$$
C_{\mathrm{p}}=4 \pi \cdot A_{\mathrm{p}} / P_{\mathrm{p}}^{2}
$$

where

$C_{\mathrm{p}} \quad$ circularity of patch $\mathrm{p}$

$A_{\mathrm{p}}$ area of patch $\mathrm{p}$

$P_{\mathrm{p}}$ perimeter of patch $\mathrm{p}$ 

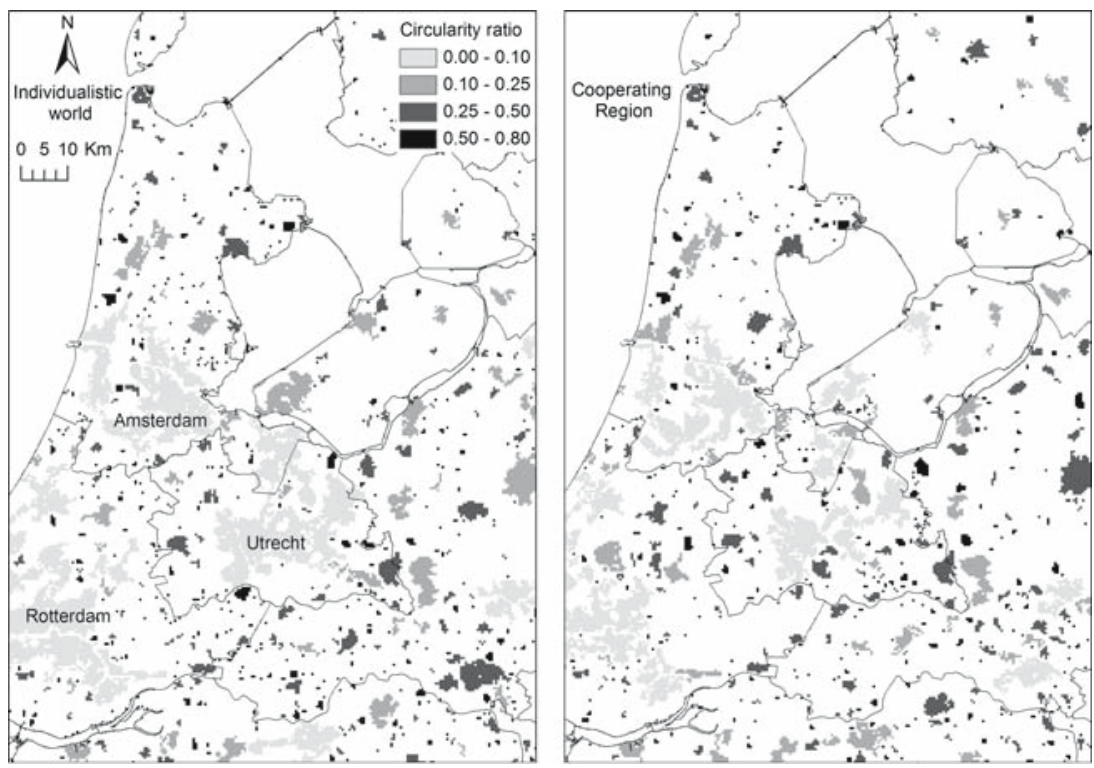

Fig. 2 Circularity ratio of urban areas in the two scenarios; high values indicate compact forms

A shape that resembles a circle will have a value close to one, whereas a very elongated form will result in a value close to zero. To characterize the compactness of urban forms in each scenario we have calculated an average circularity ratio. This average is weighted for each individual patch according to its surface area in order to reflect its relative importance. The compactness of the major agglomerations is thus considered more important than that of the small villages. Applied to our simulation we find that the average circularity decreases in both scenarios (Table 1). This decrease is strongest for the Individualistic World scenario, which is in line with our expectations regarding more irregular urbanisation patterns in this free market oriented scenario. The urbanisation patterns, on average, remain more compact in the Cooperating Region scenario that offers more constraints to spatial development.

Our analysis furthermore shows that, in practice, the circularity ratio of an urban area, despite being size independent in theory, has a strong negative correlation with its size. After logarithmic transformation of urban size, Pearson's $r$ equals -0.89 for the current situation. This correlation is equally strong in the Individualistic World ( $r=-0.86)$ and Cooperating Region scenario $(r=-0.87)$. The correlation of circularity and size of the individual urban areas is also apparent in the geographical depiction of the circularity ratio in Fig. 2 that, by way of example, shows the central part of the Netherlands according to the two scenarios. The map shows that the large urban agglomerations that contain the biggest cities (e.g. Amsterdam, Rotterdam, Utrecht) have circularity ratios of below 0.1 and are thus, based on their shape, not considered to be compact, whereas most smaller cities have much higher circularity indices, up to 0.5 . The biggest cities are however typical examples of the concentration of urbanisation that is an objective of Dutch spatial policy. The 
circularity ratio thus has to be used with caution. It is well suited to differentiate between the average urban compactness in scenarios, but it should not be applied to compare the compactness of individual urban areas that have large differences in size.

\section{Land-use diversity}

Measures for diversity of land use in a raster cell can be derived from equivalent indices in ecology that for example measure biodiversity. A distinction can be made between distributional measures, which indicate the number of species and the distribution of individuals over those species, and measures of variation, which measure the size and importance of the differences between the species present. Although it would be useful to have indices which combine both aspects, measuring both the distribution of individuals over the species and the degree to which these species differ from one another, at present such an index does not seem to be available (Baumgärtner 2004). For measuring land-use diversity the first aspect, the distribution (of land over different uses) is crucial. Therefore, we will only discuss the distributional measures. There are four basic measures in general use; it can be shown that these four are all equivalent to special cases of the so called Renyi diversity profile (Magurran 1988).

A first, very simple measure is the species richness $\mathrm{m}$ : in our case the number of different land-use types within a raster cell. This ranges from 1 to $n$ (the total number of land-use types that are distinguished). In ecology the species richness is considered to be an important characteristic of a habitat, but for application on land uses it seems to be less suitable since the presence or absence of very small areas of different land uses (as a result of scale dependencies and the resolution of the base data, but in model results for the scenarios also as a result of model uncertainties) is not very meaningful.

A second, also very simple measure is the dominance $p_{\max }$ : the proportion of the largest function within the raster cell. The reciprocal of the dominance, or $1 / p_{\max }$, is known as the Berger-Parker index. This ranges from 1 (if only a single land use is present) to $m$ (for an equal share of all land uses), and may be interpreted as an effective function richness. A notable limitation of the dominance and the Berger-Parker index is that these measure are exclusively based on the proportion of one land-use type (the largest one), effectively ignoring all information about the distribution of the other land uses.

A third group of measures is based on the notion of entropy from the information theory of Shannon and Wiener. The entropy $H$, is calculated as: $H=-\sum_{i=1}^{n} p_{i} \ln p_{i}$. This ranges from 0 (if only a single land use is present) to $\ln m$ (for an equal share of all land-use types). From the entropy we can compute an effective function richness: $e^{H}$ (ranging from 1 to $m$ ), as well as a proportionality-index: $\frac{H}{\ln m}$ (ranging from 0 to 1$)$. Entropy and other measures from this family are sensitive to the distribution of the size of all land uses within a raster cell. They also have some interesting mathematical properties. It is possible to hierarchically decompose the entropy into effects on different levels of scale (Baumgärtner 2004 p. 11). We could, for instance, decompose the total entropy into the entropy connected with mixing of urban and rural land uses, the entropy connected with mixing of different types of urban land 

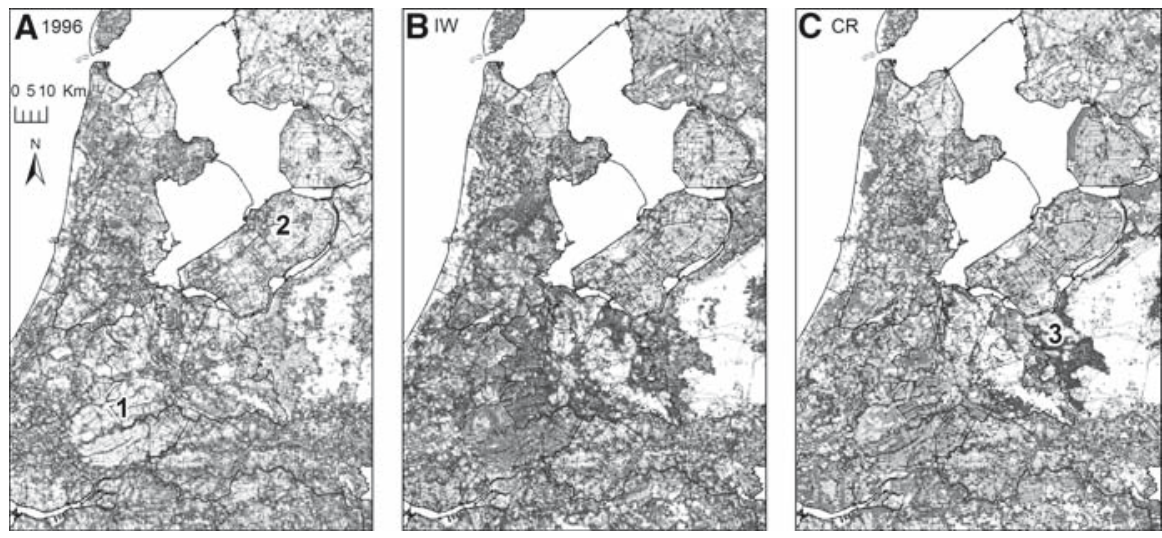

Fig. 3 Simpson's diversity index for current, 1996, land use (a), the Individualistic World (b) and Cooperating Region (c) scenario; dark colours denote a higher diversity, numbers are referred to in the text

use, and the entropy connected with the mixing of different types of rural land uses. A similar decomposition is possible for effects of different levels of spatial aggregation. A drawback however is that these measures do not have a simple, intuitive interpretation.

Finally there is a group of measures which is based on the probability that two random locations within a raster cell have different functions. This probability is often referred to as Simpson's diversity index $S$ (although the same name is in use for the other measures of this family) and is calculated as $S=1-\sum_{i=1}^{n} p_{i}^{2}$. It ranges from 0 to $1-\frac{1}{m}$. Based on this is an effective function richness $\frac{1}{1-S}$ (ranging from 1 to $m$ ). Also based on $S$ is the proportionality index $\frac{S}{\left(1-\frac{1}{m}\right)}$ (ranging from 0 to 1 ). It may be noted that $1-S$ is equivalent to the Herfindahl index (Baumgärtner 2004, p. 8) which is used in economics as an indicator for concentration (monopoly vs. perfect competition) in a market. Just as the measures of the entropy family, the Simpson indices are sensitive to the distribution of the size of all land uses within a raster cell. In comparison to the entropy measures, they are more sensitive to the largest land-use category and less sensitive to the smallest categories. It appears that when applied to diversity of land uses, both groups of measures tend to give very similar results. In our case study we tried both the entropy measure and Simpson's index, and although the numeric values were of course different, after rescaling to a range of 0 to 1 both measures resulted in maps that were virtually indistinguishable. Because of the intuitively appealing interpretation of Simpson's diversity index we selected it for this application.

When Simpson's diversity index is computed for all grid cells of the Netherlands (excluding large water bodies) we find an average value of 0.38 and a standard deviation of 0.21 . Striking features on the map (Fig. 3A) are a number of areas with very little mixed land use: large nature areas such as the glacial ridges in the central/east part of the country, large-scale agricultural meadows in the Green Heart (indicated with number 1) and extensive tracts of arable land in the IJsselmeerpolders (indicated with 
Table 2 Diversity indicators for current and simulated land use

\begin{tabular}{llll}
\hline & Current land use & Individualistic World & Cooperating Region \\
\hline Average diversity index & 0.38 & 0.41 & 0.37 \\
SD of diversity index & 0.21 & 0.23 & 0.21 \\
\hline
\end{tabular}

a 2). In these areas, we find some more mixed land use along the main transport infrastructure. Other areas with moderately mixed land use (diversity indices around 0.50 ) are found in the small scale agricultural areas (in the southern and eastern parts of the country) and in urban areas. High diversity index values (around 0.75 ) are found along the rivers and motorways, in villages and, not surprisingly, on the edges of urban areas, as transition zones are by definition areas of diversity.

In both scenario's, the overall diversity does not change very much (see Table 2). It should be kept in mind that, in a logit-type land-use model such as the one used here, the general degree of mixing can be controlled rather directly by the $\beta$ parameter: a large $\beta$ leads to monofunctional land use and a $\beta$ close to 0 leads to very mixed land use (see also Hilferink and Rietveld 1999). The fact that the overall diversity does not change very much confirms that a plausible value for $\beta$ has been used. Behind this overall stability are clear changes in the spatial structure of land-use diversity. On the map of future land-use diversity in the Individualistic World scenario (Fig. 3B), we see that the nature areas become more monofunctional whereas the agricultural areas become more mixed in terms of land use, and thus less exclusively agricultural. Especially in the Green Heart land use becomes much more mixed (new nature, residential and work areas as well as dairy farming close together). Another striking development is the trend towards monofunctionality in the cities: whereas in present land use the urban areas have a relatively high diversity index, in the Individualistic World scenario they stand out as areas with relatively low diversity. This conforms to the compact city policy guidelines to concentrate urbanisation in and near existing urban areas, though it conflicts with the preference for mixed land use in city centres and subcentres. In the Cooperating Region scenario, the general picture looks similar, although the rise of diversity in the Green Heart and some other areas is not as clearly marked as in Individualistic World.

Specific for the Cooperating Region scenario (Fig. 3C) are areas with very high diversity along the edges of nature areas, particularly prominent around the glacial ridges of the Veluwe and Utrechtse Heuvelrug (indicated with number 3). These areas are at present predominantly agricultural and characterized by livestock keeping (mainly fowl). The Cooperating Region scenario, however, pinpoints these areas as relatively attractive for a multitude of functions that are not allowed in the nearby nature areas. Especially low-density residential land use rises sharply but also recreation, agriculture and some industry and services find their place here. It is not quite clear that these functions can be combined on this scale; the model does not contain checks on improbable combinations of land uses. In any case, it is clear that these areas do have a certain potential for a wide variety of different land uses. The model 
thus pinpoints at potential 'hot-spots' for mixed land use that can be of great interest to policymakers.

\section{Discussion and conclusions}

The presented set of indicators allows for a critical comparison of the land-use patterns in the two opposing scenarios with respect to the selected policy themes of urban concentration and land-use diversity. Single indicators capture individual aspects of urbanisation like magnitude (through general composition indices), spatial pattern (grid cell based urbanisation degree), concentration (patch size distribution), compactness (average urban area circularity) and mixing of land uses (grid cell based diversity indices). It is, however, the combined use of composition and configuration indicators at various scale levels that makes it possible to unambiguously interpret the projected spatial developments. In fact, focussing on a single indicator can often be misleading, as was also discussed by $\mathrm{Li}$ and $\mathrm{Wu}$ (2004). A high average degree of compactness, for example, is not necessarily preferable from a spatial-policy perspective, if this compactness is associated with a large number of small, compact urban areas as this may pose a serious risk to open space fragmentation. Another example: mixed land use in general may be seen as a desirable objective, but much depends on which land uses are actually mixed. A combination of urban and rural land uses, for example, may create environmental tension with respect to issues such as pollution, disturbance et cetera.

The application of the circularity ratio as a shape-complexity indicator to compare the compactness of individual urban areas is found to be misleading in our case as there is a negative correlation of compactness and size of the urban areas. This does however not imply that shape-complexity measures in general are useless in this respect. Guerois (2003), for example, has proven the potential of such indicators to classify relatively equal-sized urban agglomerations in terms of compactness in an extensive study on the morphology of around 100 European cities. Her analysis related to a specific selection of relatively large towns (of over 200,000 inhabitants) and did thus not include the major size differences that are typical of our study.

Most of the presented indicators focus on concentrations formed by contiguous areas or patches. The remaining, grid cell based indicators (urbanisation degree and diversity) focus on land use in single grid cells. We did not explicitly analyse indicators that quantify concentrations formed by the proximity of sets of urban areas. Thinh et al. (2002) describe an elaborate method to assess this type of concentration. Analogous to the physical law of gravity the degree of interaction of all pairs of urban cells within an urban cluster is calculated, dependent on their urban surface area and mutual distance. The mean value of all interaction values of an urban cluster is taken as a measure for its compactness; interaction is expected to be strong when the city's structure is more compact. Applied to over 100 German cities their results are, however, similar to our experience with shape complexity measures: the large urban conglomerations of (Hamburg, Berlin) have a relatively low compactness.

In the beginning of this paper, we presented four criteria for the effectiveness of indicators to be used in the policy-related evaluation of land-use simulations: they should 
relate to specific policy themes, be intuitively understandable for policy makers, capture the essence of the simulation results and discriminate between different simulation outcomes. The indicators in this paper were selected on the basis of their relation to the policy themes of compact urbanisation and mixing of land use. They were also chosen to be easily understandable for policy makers and the interested public. Especially the use of dedicated graphical as well as tabular output was found to be very helpful in this respect. Furthermore, all indicators were shown to clearly discriminate between the two scenarios, either on an aggregate scale or at the local level (individual grid cells). The question whether they capture the essence of the simulation results is more difficult to answer. Generally it seems to us that the relevant aspects of the results are well summarized by the indicators of general composition (urbanisation degree), regional configuration (patch size and circularity ratio) and local composition (urbanisation degree and diversity index). However, the exact implementation (for instance the size of the grid cells used) may have a large influence on the results. Ideally, the policy theme should dictate the implementation of the indicator. For example, on which scale is mixing of land uses relevant? This may differ from place to place: in woodland, a small residential development is virtually invisible from a distance of more than $100 \mathrm{~m}$, whereas in large-scale grasslands it may totally change the landscape as viewed from a distance of several kilometres. In actual applications for policy analysis, aspects such as these should be considered early in the implementation phase of the project.

The importance of scale in implementing and interpreting indicators can hardly be overstressed. Spatial scale (e.g. grid cell size), thematic scale (e.g. land-use typology) and extent (e.g. study area) are crucial in the application and interpretation of indicators in land-use simulation. This has been discussed by many scholars (amongst others: Turner et al. 1989; Verburg and Chen 2000; Li and Wu 2004) and also proved true in our case. The impact of spatial scale is demonstrated by the urban area size dependency of our application of shape-complexity indicator, as was discussed before. The relevance of thematic scale was analysed in a basic sensitivity analysis of the diversity measures (Koomen et al. 2005b) that showed that a decrease in the number of distinguished land-use types directly corresponds to a less rich representation of land-use diversity. Areas with specific mixes of strongly contrasting land use types are, however, more easily recognised from applications with a limited number (five or eight rather than the original 14) of land-use types. This is for instance the case for areas with a mix of urban and rural land uses. The appropriate thematic resolution thus depends on the exact type of diversity that needs to be evaluated.

The presented model results are based on a series of assumptions, choices and interpretations (part of them are implicit in the model that was used) and can by no means be considered as an exact prediction of future land-use patterns. The opposing outcomes of the two scenarios do however provide insight in the possible consequences of future socio-economic conditions and the implications of spatial policy related choices. The simulation results for the Individualistic World scenario for example indicate that the stronger emphasis on economic development combined with less restrictive spatial policies that is the current aim of the central government may lead to more extensive forms of urbanisation that could threaten natural and recreational values. The results maps also show where these problems are most likely to occur. 
Therefore, they may be especially useful as a starting point for locally targeted policy measures to counteract expected negative local consequences of general developments and generic policy.

Acknowledgments Part of this research was sponsored by the Dutch National research program 'Climate changes spatial planning'. Furthermore, the authors wish to thank two anonymous reviewers for their constructive comments on an earlier version of this paper.

\section{References}

Agarwal C, Green GM, Grove JM, Evans TP, Schweik CM (2002) A review and assessment of land-use change models: dynamics of space, time, and human choice. Gen Tech Rep NE-297, U.S. Department of Agriculture, Forest Service, Newtown Square, PA

Allen E (2001) INDEX: Software for community indicators. In: Brail RK, Klosterman RE (eds) Planning supporting systems: integrating geographic information systems, models, and visualization tools. ESRI Press, Redlands, pp 229-261

Baumgärtner S (2004) Measuring the diversity of what? And for what purpose? A conceptual comparison of ecological and economic measures of biodiversity. Interdisciplinary Institute for Environmental Economics, Heidelberg.

Boyce RR, Clark WA (1964) The concept of shape in geography. Geogr Rev 54:37-52

Brueckner JK (2000) Urban sprawl: diagnosis and remedies. Int Region Sci Revi 23:160-171

de Nijs T, Crommentuijn L, Farjon H, Leneman H, Ligtvoet W, de Niet R, Schotten K (2002) Vier scenario's van het Landgebruik in 2030, Achtergrondrapport bij de Nationale Natuurverkenning 2. RIVM-rapport 408764 003, RIVM, Bilthoven

de Nijs TCM, de Niet R, Crommentuijn L (2004) Constructing land-use maps of the Netherlands in 2030. J Environ Manage 72:35-42

Dieleman FM, Dijst MJ, Split T (1999) Planning the compact city: the Randstad Holland experience. Euro Plann Stud 7(5):605-621

Frenkel A (2004) The potential effect of national growth management policy on urban sprawl and the depletion of open spaces and farmland. Land Use Policy 21(4):357-369

Geurs KT, van Wee B (2006) Ex-post evaluation of thirty years of compact urban development in the Netherlands. Urban Stud 43(1):139-160

Glaeser E, Kahn M (2004) Sprawl and urban growth. In: Henderson V, Thisse JF (eds) Handbook of regional and urban economics: cities and geography. Handbooks in economics, vol 4. Elsevier, Amsterdam

Guerois M (2003) Les formes des villes européennes vues du ciel, Une contribution de l'image CORINE à la comparaison morphologique des grandes villes d'Europe occidentale, Thèse, Université Paris I Pantheon-Sorbonne

Gustafson EJ (1998) Quantifying landscape spatial pattern: what is the state of the art? Ecosystems 1:143156

Hall P (1998) Cities in Civilization. Weidenfeld and Nicolson, London.

Hilferink M, Rietveld P (1999) Land Use Scanner: an integrated GIS based model for long term projections of land use in urban and rural areas. J Geogr Syst 1(2):155-177

Jaeger J (2000) Landscape division, splitting index, and effective mesh size: new measures of landscape fragmentation. Lands Ecol 15(2):115-130

Jenerete GD, Wu J (2001) Analysis and simulation of land-use change in the central Arizona-Phoenix region, USA. Lands Ecol 16:611-626

Johnston RJ, Voas D, Poulsen MF (2003) Measuring spatial concentration: the use of threshold profiles. Environ Plann B 30:3-14

Klosterman RE (1999) The What-If ? collaborative planning support system, Environ Plann B. 26:393-408

Koole B, Luijt J, Voskuilen MJ (2001) Grondmarkt en grondgebruik-Een scenariostudie voor Natuurverkenning 2, Werkdocument 2001-212, Landbouw-Economisch Instituut, Den Haag

Koomen E, Kuhlman T, Groen J, Bouwman A (2005a) Simulating the future of agricultural land use in the Netherlands. Tijdschrift voor Economische en Sociale Geografie 96(2):218-224

Koomen E, Kuhlman T, Loonen W, Ritsema van Eck J (2005b) De Ruimtescanner in 'Ruimte voor landbouw'; data- en modelaanpassingen, Vrije Universiteit Amsterdam 
Koomen E, Stillwell J, Bakema A, Scholten HJ (2007) Modelling land-use change; progress and applications, GeoJournal Library, vol. 90, Springer, Dordrecht

Li H, Wu J (2004) Use and misuse of landscape indices, Landsc Ecol 19:389-399

Longley PA, Mesev V (2000) On the measurement and generalization of urban form. Environ Plann A, 32:473-488

Magurran AE (1988) Ecological diversity and its measurement, Princeton university press, Princeton

McGarigal K (2002) Landscape pattern metrics. In: El-Shaarawi AH, Piegorsch WW (eds) Encyclopedia of environmetrics, vol 2. Wiley Sussex, pp 1135-1142

McGarigal K, Marks BJ (1995) FRAGSTATS: spatial pattern analysis program for quantifying landscape structure. General Technical Report PNW-GTR-351, USDA Forest Service, Pacific Northwest Research Station, Portland

Medda F (2000) The assembled city. Ph.D. thesis, Thela Thesis, Amsterdam.

MNP (2002) Nationale Natuurverkenning 2, 2000-2030, Milieu- en Natuurplanbureau/Kluwer, Alphen aan de Rijn

Nagendra H, Munroe DK, Southworth J (2004) Introduction to the special issue; from pattern to process: landscape fragmentation and the analysis of land use/land cover change. Agric Ecosyst Environ 101:111-115

NAI (2004), Exposition 'Hybrid Landscapes', Schalkwijkse kom, Nederlands Architectuur Instituut http://www.nai.nl/pagpdfs/hybride_schalkwijk.pdf, last accessed: 22 June 2005

O’Neill RV, Riitters KH, Wickham JD, Jones KB (1999) Landscape pattern metrics and regional assessment. Ecosyst Health 5(4):225-233

RNP (1958) De ontwikkeling van het Westen des Lands, Rijksdienst voor het Nationale Plan, Den Haag

Scholten HJ, van de Velde R, Rietveld P, Hilferink M (1999) Spatial information infrastructure for scenario planning: the development of a land use planner for Holland. In: Stillwell J, Geertman S, Openshaw S (eds) Geographical information and planning, Springer, Berlin, pp 112-134

Schotten CGJ, Goetgeluk R, Hilferink M, Rietveld P, Scholten HJ (2001) Residential construction, land use and the environment. Simulations for the Netherlands using a GIS-based land use model. Environ Model Assess 6:133-143

Selkirk KE (1982) Pattern and place an introduction to the mathematics of geography. Cambridge University Press, Cambridge

Solecki WD, Oliveri C (2004) Downscaling climate change scenarios in an urban land use change model. J Environ Manage 72:105-115

Song Y, Knaap G (2004) Measuring urban form: is Portland winning the war on sprawl? J Am Plann Assoc $70(2): 210-225$

Statistics Netherlands (1996): land use registration 1996 (CBS Bodemstatistiek 1996). Voorburg: CBS

Thinh NX, Arlt G, Heber B, Hennersdorf J, Lehmann I (2002) Evaluation of urban land-use structures with a view to sustainable development. Environ Impact Assess Rev 22:475-492

Turner MG, O’Neill RV, Gardner RH, Milne BT (1989) Effects of changing spatial scale on the analysis of landscape pattern. Landscape Ecol 3:153-162

Turner MG, Gardner RH, O’Neill RV (2001) Landscape ecology in theory and practice. Patt Process. Springer, New York

V\&B (1960) Nota inzake de ruimtelijke ordening in Nederland, Ministerie van Volkshuisvesting en Bouwnijverheid staatsdrukkerij en uitgeverijbedrijf, Den Haag

V\&RO (1966) Tweede Nota over de Ruimtelijke Ordening, Ministerie van Volkshuisvesting en Ruimtelijke ordening, Staatsuitgeverij, Den Haag

V\&RO (1977) Derde Nota over de Ruimtelijke Ordening (verstedelijkingsnota), Ministerie van Volkshuisvesting en Ruimtelijke ordening, Staatsuitgeverij, Den Haag

van Dam F, Bijlsma L, van Leeuwen M, Pálsdottir HL (2005) De Landstad, landelijk wonen in de netwerkstad. NISR/NAI, The Hague/Rotterdam

Veldkamp A, Lambin EF (2001) Editorial; Predicting land-use change. Agric Ecosyst Environ 85:1-6

Veldkamp A, Verburg PH, Kok K, de Koning GHJ, Priess J, Bergsma AR (2001) The need for scale sensitive approaches in spatially explicit land use change modelling. Environ Model Assess 6:111-121

Verburg PH, Chen YQ (2000) Multiscale characterization of land-use patterns in China. Ecosyst 3:369-385

Verburg PH, Veldkamp A (2004) Projecting land-use transitions at forest fringes in the Philippines at two spatial scales, Lands Ecol 19:77-98

Verburg PH, Veldkamp A (2005) Introduction to the Special Issue on Spatial modeling to explore land use dynamics. Int J Geogr Inform Sci 19 2:99-102 
Verburg PH, Schot PP, Dijst MJ, Veldkamp A (2004) Land use change modelling: current practice and research priorities, GeoJ 61:309-324

Vreeker R, de Groot HLF, Verhoef ET (2004) Urban multifunctional land use: theoretical and empirical insights on economies of scale, scope and diversity. Built Environ 30(4):289-307

VROM (1989) Vierde Nota over de Ruimtelijke Ordening. Ministerie van Volkshuisvesting, Ruimtelijke ordening en Milieubeheer, SDU uitgeverij, Den Haag

VROM/LNV/V\&W/EZ (2004) Nota Ruimte. Ruimte voor ontwikkeling. Ministeries van Volkshuisvesting, Ruimtelijke Ordening en Milieubeheer, Landbouw, Natuur en Voedselkwaliteit, Verkeer en Waterstaat en Economische zaken, SDU uitgeverij, Den Haag

Yang X, Lo CP (2003) Modelling urban growth and landscape changes in the Atlanta metropolitan area. Int J Geogr Inform Sci 17(5):463-488 